\title{
Changes to the picture of the UK economy - impact of the new SIC 2007 industry classification
}

Keith Brook

Department for Business, Innovation and Skills

David Matthews and Jon Darke,

Office for National Statistics

\section{Summary}

The new Standard Industrial Classification (SIC 2007) which is currently being implemented in the UK, and across Europe as NACE Rev2 ${ }^{1}$, has resulted in some major classification changes. Some key business surveys are now being collected and reported on the basis of the new SIC 2007 classification, including Workforce Jobs (WFJ) and the Annual Business Inquiry $(A B I)$. This article uses these outputs to give a first quantitative picture for key economic measures to examine the impact of the classification changes across the UK economy.

\section{Introduction}

The new SIC 2007 industry classification has been defined as a result of a European consultation, which was part of a wider United Nations (UN) review - see UN (2008). The new classification includes major changes both at the very detailed level and for higher aggregations at section level. Previous Economic and Labour Market Review (ELMR) articles have described these changes and the UK timetable for implementation - see Hughes (2008) and Hughes et al (2009).

Workforce Jobs data are now published on a SIC 2007 basis giving full coverage of industries in the UK economy. Industry detail is published for 2-digit divisions and to a more limited extent at a greater 3- or 4-digit detail, but only for Great Britain. Time histories back to 1978 have also been published which gives a first picture of trends for the new classification.

Economic data, including business counts, turnover and gross value added (GVA) which are collected as part of the Annual Business Survey (Inquiry) ${ }^{2}$, have now been published for 2008 and 2009 on a SIC 2007 basis. The coverage of the ABI is limited to the market sector of the economy 
but excludes parts of Agriculture, forestry and fishing and most of Financial services. This does not give full coverage of the economy or provide data looking back in time.

These sources will be used to give a first picture of the UK economy on the basis of the new classification and to highlight changes, for example in the share of the manufacturing and service sectors. Users are however advised not to make such comparisons on a routine basis because of the major revisions and fragmentation that has taken place both at a detailed and aggregated level. All ONS surveys and outputs will have been converted to the new SIC 2007 classification by October 2011 and users will then need to fully adopt the new classification.

\section{Workforce Jobs across the whole economy}

The business surveys which are used to collect detailed employee jobs data were converted to SIC 2007 in 2010. Implementation for the Labour Force survey (LFS) was completed towards the end of 2009, although initially this only impacted on the release of the micro datasets. Workforce Jobs (WFJ) on a SIC 2007 basis were first published in the Labour Market Statistics bulletin in July 2010 and are given by the sum of the converted Employee Jobs series and self-employment from the converted LFS. In addition there are small contributions from administrative sources for HM Forces and Government supported trainees, but these together only account for less than 1 per cent of all jobs. Quarterly seasonally adjusted Workforce Jobs estimates are published for each SIC 2007 section, which is a major improvement, particularly for services due to an increase in the number of sections. Previously, a number of sections had been combined for publication on the old SIC 2003 basis.

In addition to implementing SIC 2007; the latest Workforce Jobs estimates have been subject to other significant methodological changes, which were also implemented for the July 2010 release. These include a change in the estimation method and benchmarking to the latest Annual Business Inquiry (ABI/1) employment data, which has also been converted to SIC 2007. Details of the changes are discussed in a recent ELMR article (see Barford 2010). Revisions to employee job totals occurred between March 2006 and June 2009 as a result of the methodological changes and these are independent of any classification changes. Correlations given in this article generally exclude this time period so that differences are known to be due to classification revisions, rather than the other methodological changes.

Workforce Jobs data cover the whole economy and backcast time series have also been published, extending back to 1978. A summary of how the backcast series have been derived is given in Box 1. The available data on both classifications give a first insight into the impact of the classification changes across the whole economy and looking back in time. A fuller picture including National Accounts measures will be available in late 2011 when National Accounts outputs are first published on a SIC 2007 basis. 


\section{Box $1 \quad$ Producing backcasts of Workforce Jobs data}

Historical SIC 2003 based Employee Jobs data have been converted to SIC 2007 at a detailed industry level using conversion matrices based on an apportionment method which has been derived from dual coded employment data on the Inter-Departmental Business Register (IDBR). This is available for April 2009 and the same IDBR proportions have been applied to the series from 1978 to April 2009. This approach is consistent with that adopted by other National Statistics Institutes and in the last major classification revisions in 1992. From 2008 Q3, a micro-method was used for estimates that feed from the Short Term Employee Survey (STES). Individual survey responses given on a SIC 2003 basis were re-weighted and reaggregated to produce SIC 2007 based estimates. This micro-method is considered to be more reliable than the conversion matrix approach used for the longer term time series. The STES was re-designed and collected on a SIC 2007 basis from 2010 Q1 and there is the possibility that some discontinuities exist relative to 2009 Q4. Further details are given by Barford (2010).

Table 1 gives a comparison of the level and share of Workforce Jobs in December 2009 for each section defined by the new and old classifications. There are considerable improvements to the available section detail within services, since SIC 2003 section $\mathrm{K}$ - Real estate and other business services, which accounted for over 17 per cent of UK Workforce Jobs, has been split into a number of new sections. The new SIC 2007 sections J - Information and communication, M - Professional, scientific and technical activities and $\mathrm{N}$ - Administrative and support services now account for 3.7, 7.4 and 7.5 per cent of UK Workforce Jobs respectively.

The overall effect of the classification changes has been that the service share of the economy has increased slightly from 81.9 per cent under SIC 2003 to 82.5 under SIC 2007 in December 2009. The effect on the share of manufacturing has been greater with a drop from 9.2 per cent under SIC 2003 to 8.4 per cent under SIC 2007. This is partly due to publishing moving to services and also parts of manufacturing such as recycling moving to section $E$ in production. The longer term impact on the share of services and manufacturing Workforce Jobs is shown in Figure 1. As expected, the changes are more pronounced in 1978 when the share of jobs in manufacturing was more than double the current share.

While comparing the two classifications is often not practical at a detailed level there is reasonable correlation in content between groups of SIC 2007 and SIC 2003 sections, with the exception of SIC 2007 section $\mathrm{J}$ - Information and communication which has been formed from parts of three SIC 2003 sections. In a number of cases, sections have retained names or SIC 2007 titles are similar to previous SIC 2003 titles. Figure 2 shows the number of Workforce Jobs in December 2009 using previously published SIC 2003 groupings and best matches for comparable SIC 2007 groupings. The largest difference, an increase of 0.8 million is for Transport and communication which on a SIC 2007 basis includes all of the new Information and communication section. Computer and broadcasting services are now included and this is not covered in the SIC 2003 grouping. All of the other groupings have changed by between 0.1 and 0.3 million with some gains and some losses so that the combined change is zero. 


\section{Table $1 \quad$ Workforce Jobs on SIC 2003 and SIC 2007, December 2009}

\begin{tabular}{|c|c|c|c|c|c|c|c|}
\hline Section & SIC2007 Industry & Thousands & Per cent & Section & SIC2003 Industry & Thousands & Per cent \\
\hline A & Agriculture, forestry \& fishing & 391 & $1.3 \%$ & A-B & Agriculture \& fishing & 480 & $1.6 \%$ \\
\hline$B-E$ & Production & 2,887 & $9.4 \%$ & C-E & Production & 3,025 & $9.8 \%$ \\
\hline B & Mining \& quarrying & 60 & $0.2 \%$ & $\mathrm{C}$ & Mining \& quarrying ${ }^{1}$ & 71 & $0.2 \%$ \\
\hline C & Manufacturing & 2,581 & $8.4 \%$ & $\mathrm{D}$ & Manufacturing & 2,833 & $9.2 \%$ \\
\hline D & Electricity, gas, steam \& air conditioning & 84 & $0.3 \%$ & $E$ & Electricity, gas \& water supply ${ }^{1}$ & 121 & $0.4 \%$ \\
\hline$E$ & Water supply, sewerage $\&$ waste & 162 & $0.5 \%$ & \multicolumn{4}{|c|}{ Split from section $E$, sewerage \& waste from section $O$} \\
\hline $\mathrm{F}$ & Construction & 2,108 & $6.9 \%$ & $\mathrm{~F}$ & Construction & 2,068 & $6.7 \%$ \\
\hline G-S & Services & 25,367 & $82.5 \%$ & G-O & Services & 25,181 & $81.9 \%$ \\
\hline G & Wholesale \& retail trade & 4,701 & $15.3 \%$ & G & Distribution $^{1}$ & 4,862 & $15.8 \%$ \\
\hline $\mathrm{H}$ & Transport \& storage & 1,460 & $4.7 \%$ & I & Transport \& communications & 1,803 & $5.9 \%$ \\
\hline I & Accommodation \& food services & 1,894 & $6.2 \%$ & $\mathrm{H}$ & Hotels \& restaurants ${ }^{1}$ & 1,902 & $6.2 \%$ \\
\hline J & Information \& communication & 1,128 & $3.7 \%$ & \multicolumn{4}{|c|}{ From parts of sections $I, K$ and $O$} \\
\hline $\mathrm{K}$ & Financial \& insurance activities & 1,107 & $3.6 \%$ & $\mathrm{~J}$ & Financial $^{1}$ & 1,061 & $3.4 \%$ \\
\hline L & Real estate activities & 430 & $1.4 \%$ & $\mathrm{~K}$ & $\begin{array}{l}\text { Real estate \& other business } \\
\text { services }^{1}\end{array}$ & 5,318 & $17.3 \%$ \\
\hline M & Professional, scientific \& technical activities & 2,282 & $7.4 \%$ & \multicolumn{4}{|c|}{ Split from section $K$} \\
\hline $\mathrm{N}$ & Administrative \& support services & 2,317 & $7.5 \%$ & \multicolumn{4}{|c|}{ Split from section $K$} \\
\hline $\mathrm{O}$ & Public administration \& defence & 1,760 & $5.7 \%$ & $\mathrm{~L}$ & Public administration ${ }^{1}$ & 1,579 & $5.1 \%$ \\
\hline $\mathrm{P}$ & Education & 2,706 & $8.8 \%$ & M & Education $^{1}$ & 2,696 & $8.8 \%$ \\
\hline Q & Human health \& social work activities & 3,919 & $12.7 \%$ & $\mathrm{~N}$ & Health \& social work ${ }^{1}$ & 4,010 & $13.0 \%$ \\
\hline $\mathrm{R}$ & Arts, entertainment \& recreation & 819 & $2.7 \%$ & $\mathrm{O}$ & Other personal services & 1,949 & $6.3 \%$ \\
\hline $\mathrm{S}$ & Other service activities & 844 & $2.7 \%$ & \multicolumn{4}{|c|}{ Split from section $O$} \\
\hline A-S & Total UK Workforce Jobs & 30,753 & $100.0 \%$ & $\mathrm{~A}-\mathrm{O}$ & Total UK Workfoce Jobs & 30,753 & $100.0 \%$ \\
\hline
\end{tabular}

1. SIC 2003 section Workforce Jobs data estimated from published employee jobs and LFS self-employment data, adjusted to aggregations published by ONS for sections C,E; G-H; J-K and L-N.

Source: Workforce Jobs, ONS

Backcast series have been derived and published by ONS on a SIC 2007 basis and Table 2 shows the level of jobs for these section groupings at ten year intervals back to 1979. As expected, the differences between the two classifications increase for Manufacturing in earlier years and are correspondingly less for the Service industries. Where differences are small between the two classifications, it should be noted that this is a measure of a net effect and the content may be significantly different due to movements in and out of the sections. Users are advised to be cautious about making such comparisons on a routine basis and these results are presented to help in understanding and to document the change in the picture of the economy as a result of the classification changes. 
Figure 1 Share of Workforce Jobs in services and manufacturing under old and new classifications, 1978-2009

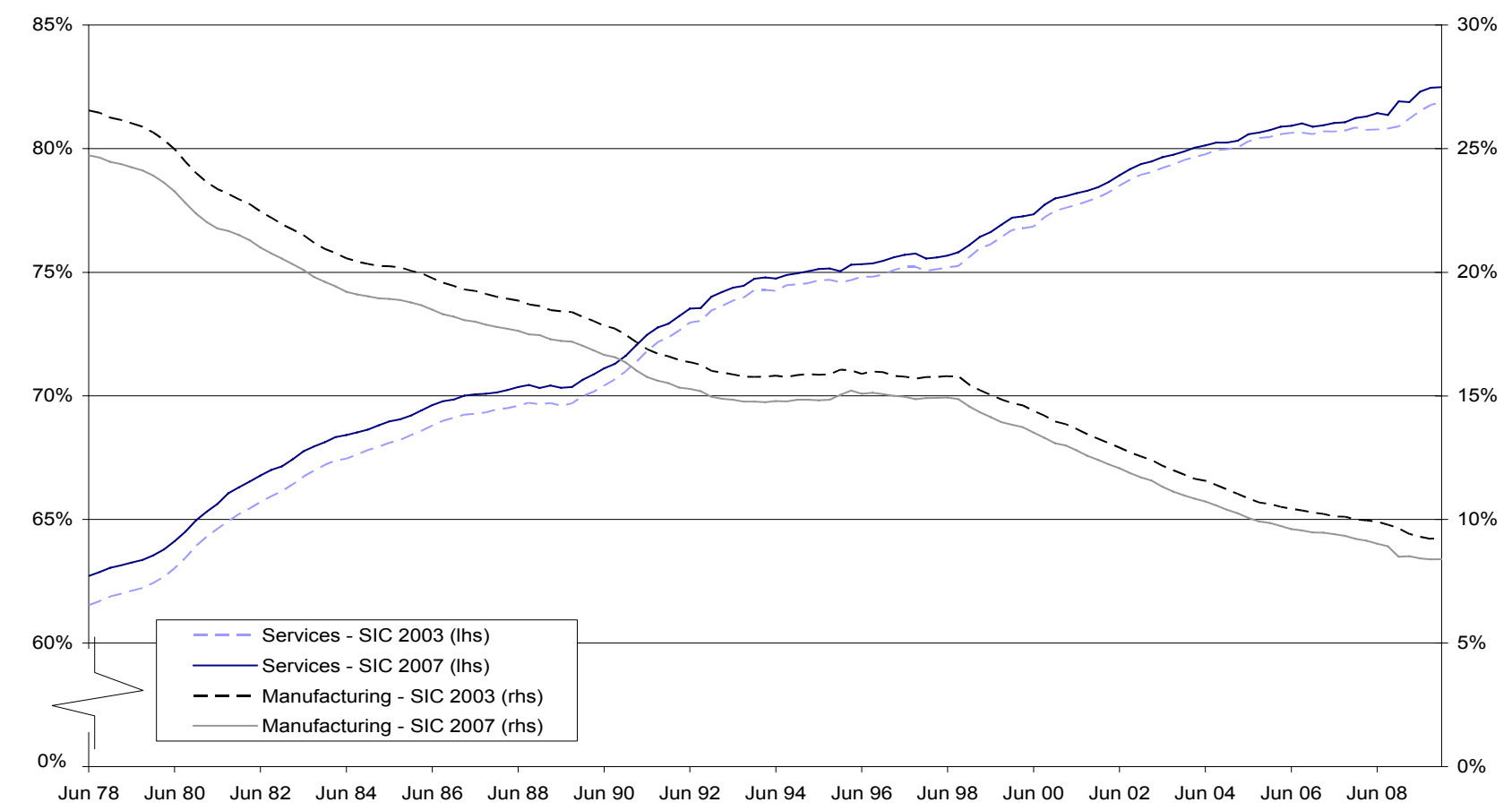

Source: Workforce Jobs, ONS

Figure 2 Number of Workforce Jobs in comparable section groupings for both classifications, December 2009

Millions, seasonally adjusted

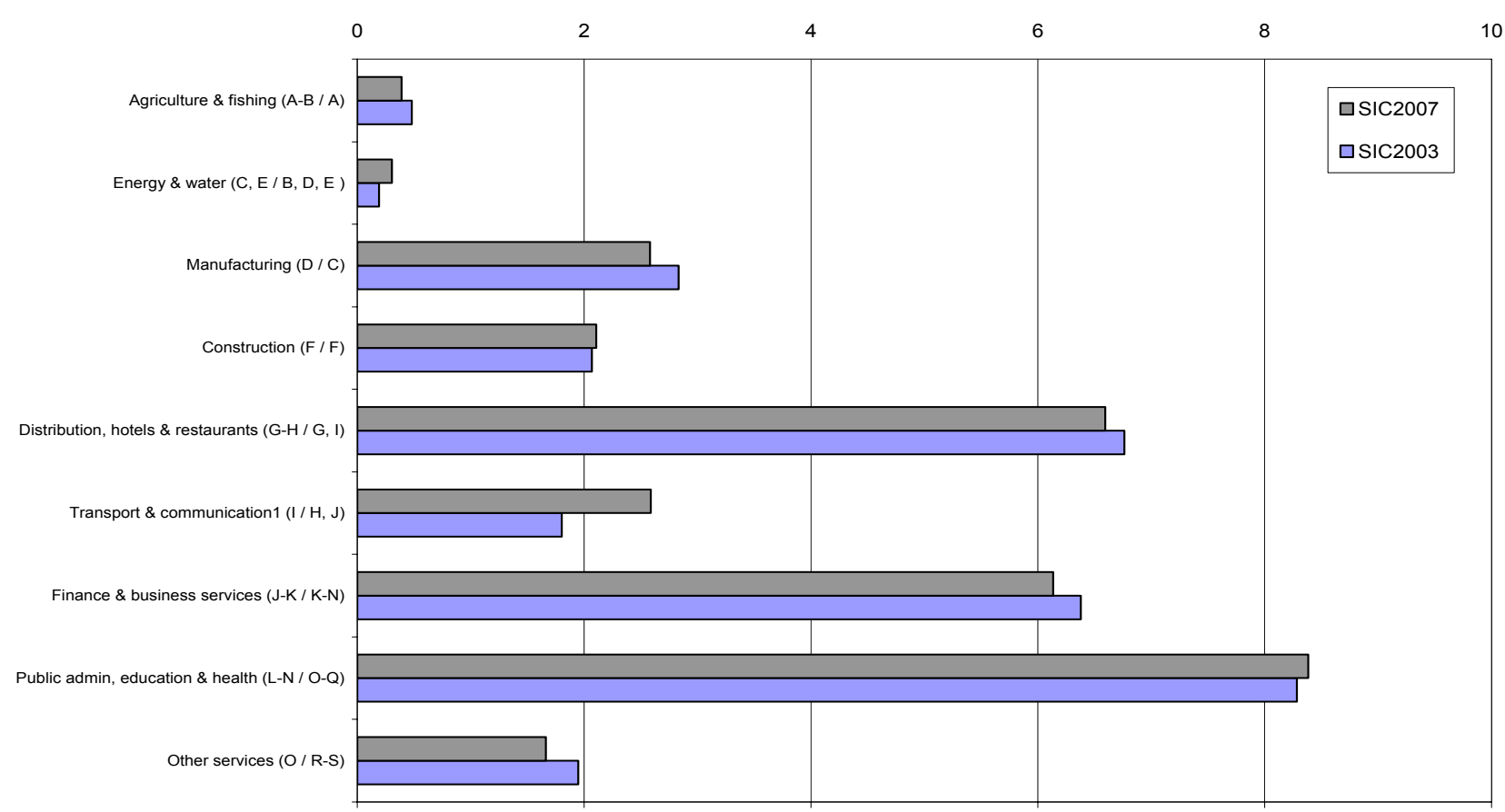

Source: Workforce Jobs, ONS 


\section{Table $2 \quad$ Number of Workforce Jobs in comparable section groupings for both classifications, 1979-2009}

Millions, seasonally adjusted

\begin{tabular}{lcccc}
\hline SIC2003 & Dec-1979 & Dec-1989 & Dec-1999 & Dec-2009 \\
\hline Agriculture \& fishing (A-B) & 0.6 & 0.7 & 0.5 & 0.5 \\
Energy \& water (C, E) & 0.7 & 0.4 & 0.2 & 0.2 \\
Manufacturing (D) & 7.0 & 5.3 & 4.3 & 2.8 \\
Construction (F) & 1.9 & 2.4 & 1.8 & 2.1 \\
Distribution, hotels \& restaurants (G-H) & 5.6 & 6.4 & 6.7 & 6.8 \\
Transport \& communication (I) & 1.7 & 1.7 & 1.7 & 1.8 \\
Finance \& business services (J-K) & 3.0 & 4.4 & 5.5 & 6.4 \\
Public admin, education \& health (L-N) & 5.7 & 6.4 & 6.8 & 8.3 \\
Other services (O) & 1.1 & 1.5 & 1.8 & 1.9 \\
\hline Total & 27.4 & 29.1 & 29.4 & 30.8 \\
\hline
\end{tabular}

\begin{tabular}{lcccc}
\hline SIC2007 & Dec-1979 & Dec-1989 & Dec-1999 & Dec-2009 \\
\hline Agriculture, forestry \& fishing (A) & 0.6 & 0.6 & 0.4 & 0.4 \\
Mining, quarrying, electricity, gas, water supply \& sewerage (B, D, E) & 0.9 & 0.6 & 0.3 & 0.3 \\
Manufacturing (C) & 6.6 & 5.0 & 4.1 & 2.6 \\
Construction (F) & 2.0 & 2.5 & 1.9 & 2.1 \\
Wholesale \& retail trade, accommodation \& food services (G, I) & 5.6 & 6.4 & 6.7 & 6.6 \\
Transport, information \& communication (H, J) & 2.3 & 2.3 & 2.5 & 2.6 \\
Financial, real estate, professional \& administrative services (K-N) & 2.9 & 4.2 & 5.2 & 6.1 \\
Public admin, education \& health (O-Q) & 5.7 & 6.4 & 6.9 & 8.4 \\
Arts, entertainment \& other (R-S) & 1.0 & 1.3 & 1.6 & 1.7 \\
\hline Total & 27.4 & 29.1 & 29.5 & 30.8 \\
\hline
\end{tabular}

\begin{tabular}{lcccc}
\hline Difference & Dec-1979 & Dec-1989 & Dec-1999 & Dec-2009 \\
\hline Agriculture, forestry \& fishing (A) & -0.1 & -0.1 & -0.1 & -0.1 \\
Mining, quarrying, electricity, gas, water supply \& sewerage (B, D, E) & 0.2 & 0.1 & 0.1 & 0.1 \\
Manufacturing (C) & -0.5 & -0.3 & -0.2 & -0.3 \\
Construction (F) & 0.1 & 0.1 & 0.1 & 0.0 \\
Wholesale \& retail trade, accommodation \& food services (G, I) & 0.0 & 0.0 & -0.1 & -0.2 \\
Transport, information \& communication (H, J) & 0.6 & 0.6 & 0.7 & 0.8 \\
Financial, real estate, professional \& administrative services (K-N) & -0.1 & -0.2 & -0.3 & -0.2 \\
Public admin, education \& health (O-Q) & 0.0 & 0.0 & 0.1 & 0.1 \\
Arts, entertainment \& other (R-S) & -0.2 & -0.2 & -0.2 & -0.3 \\
\hline Total & 0.0 & 0.0 & 0.1 & 0.0 \\
\hline
\end{tabular}




\section{$A B I$ business economic data}

SIC 2007 has been implemented in the Annual Business Inquiry (ABI) from 2008 reference year and final results were published in June 2010 with provisional 2009 estimates being published in November 2010. These give the first estimates of key economic measures such as turnover, gross value added (GVA), labour costs, purchases and business counts, on the basis of the new classification. The ABI covers most of the market sector, except for parts of Agriculture, forestry and fishing and Financial services, although parts of the latter are now being covered. All of the public sector is excluded so that the content of SIC 2007 sections O to S, and correspondingly SIC 2003 sections L to O, have only partial or no coverage.

\section{Table 3 Comparison between ABI outputs at section level on a SIC 2007 and SIC 2003 basis, 2008 reference year}

\begin{tabular}{|c|c|c|c|c|c|c|c|c|c|c|}
\hline SIC2007 & & $\begin{array}{c}\text { No of } \\
\text { enterprises } \\
\text { Thousand }\end{array}$ & $\begin{array}{l}\text { Turnover } \\
£ \text { billion }\end{array}$ & $\begin{array}{c}\text { GVA } \\
£ \text { billion }\end{array}$ & $\operatorname{SIC2003}$ & & $\begin{array}{c}\text { No of } \\
\text { enterprises } \\
\text { Thousand }\end{array}$ & $\begin{array}{l}\text { Turnover } \\
£ \text { billion }\end{array}$ & $\begin{array}{l}\text { GVA } \\
£ \text { billion }\end{array}$ & $\begin{array}{l}\text { Provisional } \\
\text { NA GVA } \\
£ \text { billion }\end{array}$ \\
\hline Mining \& quarrying & B & 1.2 & 64 & 36 & Mining \& quarrying & C & 1.2 & 64 & 36 & 38 \\
\hline Manufacturing & C & 131.8 & 503 & 150 & Manufacturing & $\mathrm{D}$ & 145.8 & 530 & 161 & 150 \\
\hline Electricity \& gas etc & D & 0.5 & 86 & 23 & Electricity, gas \& water & E & 0.6 & 88 & 24 & 21 \\
\hline Water supply \& sewerage etc & E & 5.6 & 29 & 15 & & & & & & \\
\hline Production & B-E & 139.1 & 681 & 225 & Production & C-E & 147.6 & 681 & 222 & 199 \\
\hline Construction & $\mathrm{F}$ & 292.8 & 223 & 85 & Construction & $\mathrm{F}$ & 252.5 & 205 & 76 & 81 \\
\hline Distribution & G & 370.9 & 1,230 & 157 & Distribution & G & 377.5 & 1,232 & 158 & 147 \\
\hline Transport & $\mathrm{H}$ & 72.1 & 138 & 60 & Transport \& Communication & 1 & 84.2 & 238 & 93 & 91 \\
\hline Accommodation \& food & 1 & 136.5 & 68 & 32 & Hotels, Catering \& Restaurants & $\mathrm{H}$ & 136.5 & 68 & 32 & 36 \\
\hline Information \& communication & $\mathrm{J}$ & 151.6 & 183 & 89 & & & & & & \\
\hline Financial Intermediation ${ }^{1}$ & K & $\mathrm{n} / \mathrm{a}$ & $\mathrm{n} / \mathrm{a}$ & $\mathrm{n} / \mathrm{a}$ & Financial Intermediation ${ }^{1}$ & $\mathrm{~J}$ & $\mathrm{n} / \mathrm{a}$ & $\mathrm{n} / \mathrm{a}$ & $\mathrm{n} / \mathrm{a}$ & 117 \\
\hline Real Estate & L & 75.0 & 44 & 26 & Real estate, Renting \& Other Business & $\mathrm{K}$ & 699.5 & 443 & 252 & 303 \\
\hline Professional services & M & 330.4 & 193 & 107 & & & & & & \\
\hline Administrative \& support services & N & 155.9 & 153 & 72 & & & & & & \\
\hline Public administration & $\mathrm{O}$ & $\mathrm{n} / \mathrm{a}$ & $\mathrm{n} / \mathrm{a}$ & $\mathrm{n} / \mathrm{a}$ & Public administration & L & $\mathrm{n} / \mathrm{a}$ & $\mathrm{n} / \mathrm{a}$ & $\mathrm{n} / \mathrm{a}$ & 65 \\
\hline Education (part) & $\mathrm{P}$ & 29.4 & 26 & 10 & Education (part) & M & 26.6 & 25 & 10 & 76 \\
\hline Health \& social (part) & Q & 51.5 & 33 & 21 & Health \& social (part) & $\mathrm{N}$ & 54.7 & 36 & 22 & 94 \\
\hline Arts \& recreation (part) & $\mathrm{R}$ & 58.4 & 88 & 15 & Other personal services (part) & $\mathrm{O}$ & 171.4 & 149 & 39 & 60 \\
\hline Other services (part) & s & 100.0 & 31 & 14 & & & & & & \\
\hline Distribution and services & G-S & 1531.7 & 2,187 & 604 & Distribution and services & G-O & 1550.4 & 2,190 & 606 & 990 \\
\hline Market sector (approx ${ }^{1}$ ) & A-S & 1963.5 & 3,092 & 913 & Market sector (approx $\left.{ }^{1}\right)$ & $\mathrm{A}-\mathrm{O}$ & 1950.5 & 3,077 & 904 & 1,270 \\
\hline
\end{tabular}

1. The $A B I$ survey covers most of the market services but excludes Financial services and parts of Agriculture, forestry \& fishing. Total under SIC 2003 and SIC 2007 may differ due to some companies moving in or out of scope.

Source: Annual Business Inquiry, ONS 
Limited SIC 2003 based ABI estimates have been produced and published by ONS for 2008 reference year only and these are shown in Table 3 at section level compared with the new SIC 2007 based outputs. The improvement in the service sector is evident due to section $\mathrm{K}$ being split into sections $\mathrm{L}$ to $\mathrm{N}$ and computer services moving to the new section $\mathrm{J}$ Information and communication. Provisional 2008 National Accounts GVA is also included in the table on a SIC 2003 basis, to assist in understanding the $A B I$ coverage. For sections $C$ to I, differences between the $A B I$ and National Accounts measures are mainly due to balancing effects. For the remaining sections, most of the differences are due to $A B I$ not covering the non-market sector or the inclusion of imputed rent in the National Accounts for SIC 2003 section K, which is excluded from the $A B I$ data. It is noted that the $A B I$ totals differ for the two classifications, which is because the classification changes have resulted in some movement of businesses which are in or out of scope for the $\mathrm{ABI}$.

Table 4 gives the share of the $A B I$ market services for both classifications, showing a much reduced share of SIC 2003 section $\mathrm{K}$ - Real estate, renting and other business services from 42 per cent to 18 per cent for SIC 2007 section M - Professional services, a welcome improvement. The 2006 Index of Services and whole economy weights are also shown on a SIC 2003 basis to help inform the coverage of the ABI. These weights will be published on a new SIC 2007 basis in late 2011 when National Accounts outputs are first published on the basis of the new classification.

\section{Table $4 \quad$ Share of ABI market services ${ }^{1}$ GVA on basis of SIC 2007 and SIC 2003, 2008 reference year}

2006 National Accounts weights

\begin{tabular}{|c|c|c|c|c|c|c|c|}
\hline Section & SIC2007 & $\begin{array}{c}\text { Share of } \\
\text { Market } \\
\text { Services }\end{array}$ & Sect & SIC2003 & $\begin{array}{l}\text { Share of } \\
\text { Market } \\
\text { Services }\end{array}$ & $\begin{array}{c}\text { Share of } \\
\text { All } \\
\text { Services } \\
\text { (loS) }\end{array}$ & $\begin{array}{c}\text { Share of } \\
\text { Whole } \\
\text { economy } \\
\text { (NA) }\end{array}$ \\
\hline G & Distribution & $26 \%$ & $\mathrm{G}$ & Distribution & $26 \%$ & $15 \%$ & $11 \%$ \\
\hline $\mathrm{H}$ & Transport & $10 \%$ & 1 & Transport \& Communication & $15 \%$ & $9 \%$ & $7 \%$ \\
\hline I & Accommodation \& food & $5 \%$ & $\mathrm{H}$ & Hotels, Catering \& Restaurants & $5 \%$ & $4 \%$ & $3 \%$ \\
\hline $\mathrm{J}$ & Information \& communication & $15 \%$ & & & & & \\
\hline $\mathrm{K}$ & Financial Intermediation & $\mathrm{n} / \mathrm{a}$ & J & Financial Intermediation & $\mathrm{n} / \mathrm{a}$ & $10 \%$ & $8 \%$ \\
\hline L & Real Estate & $4 \%$ & $\mathrm{~K}$ & Real estate, Renting \& Other Business & $42 \%$ & $31 \%$ & $23 \%$ \\
\hline M & Professional services & $18 \%$ & & & & & \\
\hline $\mathrm{N}$ & Administrative \& support services & $12 \%$ & & & & & \\
\hline $\mathrm{O}$ & Public administration & $\mathrm{n} / \mathrm{a}$ & L & Public administration & $\mathrm{n} / \mathrm{a}$ & $7 \%$ & $5 \%$ \\
\hline$P$ & Education (part) & $2 \%$ & M & Education (part) & $2 \%$ & $8 \%$ & $6 \%$ \\
\hline Q & Health \& social (part) & $3 \%$ & $\mathrm{~N}$ & Health \& social (part) & $4 \%$ & $10 \%$ & $7 \%$ \\
\hline $\mathrm{R}$ & Arts \& recreation (part) & $2 \%$ & $\mathrm{O}$ & Other personal services (part) & $6 \%$ & $6 \%$ & $5 \%$ \\
\hline S & Other services (part) & $2 \%$ & & & & & \\
\hline G-S & Distribution and services & $100 \%$ & G-O & Distribution and services & $100 \%$ & $100 \%$ & $75 \%$ \\
\hline
\end{tabular}

1. The Annual Business Survey (ABS) covers most of the market services but excludes Financial services and parts of Agriculture, forestry \& fishing

Source: Annual Business Inquiry, ONS 
From 2009 reference year, only SIC 2007 based data will be available for the ABI and no backcast figures have or are being produced. Extensive backcast series are being produced for the shortterm surveys, including turnover from the Monthly Business survey and data will be available from 1998 reference year. SIC 2007 based balanced annual National Account outputs will be published in 2011 or later from 1992 reference year. Constant price series will also be produced, with some at a higher aggregated level being published back to 1948 .

\section{Availability of data below Section level}

Below section level, only limited estimates have been produced or published for both classifications for the same time periods. Some ABI data have been published for 2008 reference year - see Box 2. The industry detail is limited to that used in the National Accounts Supply and Use Tables (SUTs), and due to disclosure issues some cells have been suppressed and cannot be published on a SIC 2003 basis. Detailed ABI/1 employment statistics at a Great Britain level have been produced on the basis of both classifications and this is available to NOMIS users at www.nomisweb.co.uk/Default.asp.

\section{Box 2 Disclosure checking ABI data across two classifications}

Methodological challenges exist with publishing outputs on both classifications for the same reference period since disclosure checking across the two classifications needs to be considered. To date no exact method has been developed by any of the National Statistic Institutes across the world, to allow this to be implemented at a very detailed SIC level. ONS has developed a conservative method to allow higher level aggregations to be checked and published.

2003 based ABI data have been estimated for 2008 reference year and this data has been disclosure checked across the two classifications and where it is non-disclosive this has now been published for key outputs including business count, turnover and GVA. See www.statistics.gov.uk/statbase/Product.asp?vlnk=7381

Workforce Jobs statistics are now being published on a SIC 2007 basis with backcast section estimates being available from 1978. Below section level, ONS produce Employee Jobs data for most 2-digit SIC divisions and while these are not published, they are available to users on request. Estimates for some limited industries below 2-digit, are also produced at a GB level. These are available on both classification bases from 1996 reference year and are consistent with the recent methodological changes introduced at the same time as the classification change (see Box 1). Note that due to these methodological changes, users should not compare published SIC 2007 data with any SIC 2003 based data published prior to July 2010. 
Using mainly $\mathrm{ABI}$ outputs, comparisons of outputs at detailed 2-digit industries or below are included in the next section to demonstrate the level of fragmentation that has occurred and to highlight some improvements arising from the new classification. These include selected industries in the manufacturing sector, the new business services industries and water and sewerage where there have been significant changes.

\section{Selected manufacturing industries}

Table 5 gives the $A B I$ output of selected manufacturing industries which are of policy interest to the Department for Business, Innovation and Skills (BIS) on a new SIC 2007 basis, together with the corresponding codes on a SIC 2003 basis where a majority or significant part of the old industry contributes to the new classification. In a number of cases, previous 3-digit industries have now become 2-digit industries under SIC 2007 or vice-versa. As shown in Table 5, an example of this in the manufacturing sector is the Pharmaceutical industry which is now defined as a 2-digit SIC but under SIC 2003 was defined in terms of a 3-digit code. Table 5 shows that due to the classification changes the industry is now smaller on all measures under SIC 2007 than under SIC 2003.

Figure 3 shows the fragmentation that has occurred to SIC 2003 code 24.4 - Manufacture of pharmaceuticals, medicinal chemicals and botanical products. While the majority of businesses with their turnover and employment activity have been retained in the new SIC 2007 Pharmaceutical industry, 12 per cent of businesses have been moved out of this industry into SIC 2007 code 32.5 - Manufacture of medical and dental instruments and supplies. In turnover and employment terms this is about 3 or 4 per cent of SIC 2003 code 24.4. In the case of Pharmaceuticals there has only been a two way split and no additional businesses have been added into the SIC 2007 code from other SIC 2003 codes, which is often the case.

The second example in Table 5, SIC 2007 code 26 - Manufacture of computer, electronic and optical products, illustrates a different fragmentation where the majority of three SIC 2003 2-digit codes, together with part of a fourth have been combined to form a new 2-digit SIC 2007 code. Figure 4 shows that a small part, less than 1 per cent, also comes from two other SIC 2003 codes 24 and 36. SIC 2003 code 30 - Manufacture of office machinery and computers, has now been fragmented into a number of 3-digit codes under SIC 2007.

For the remaining industries shown in Table 5 between 95 and 100 per cent of the content for the new SIC 2007 industries come from the SIC 2003 industry listed. In the last two cases, Building of ships and Manufacture of aircraft the new SIC 2007 classification gives a split between manufacturing and repair of the equipment. Note that while 100 per cent of the content of the new group or class may come from the listed SIC 2003 group, all of the content of that group may not have moved to the SIC 2007 industries listed. For these cases, less than 1 per cent has moved to other classes. 

defined under SIC 2007 with an indication of contributions from corresponding SIC 2003 industries, 2008

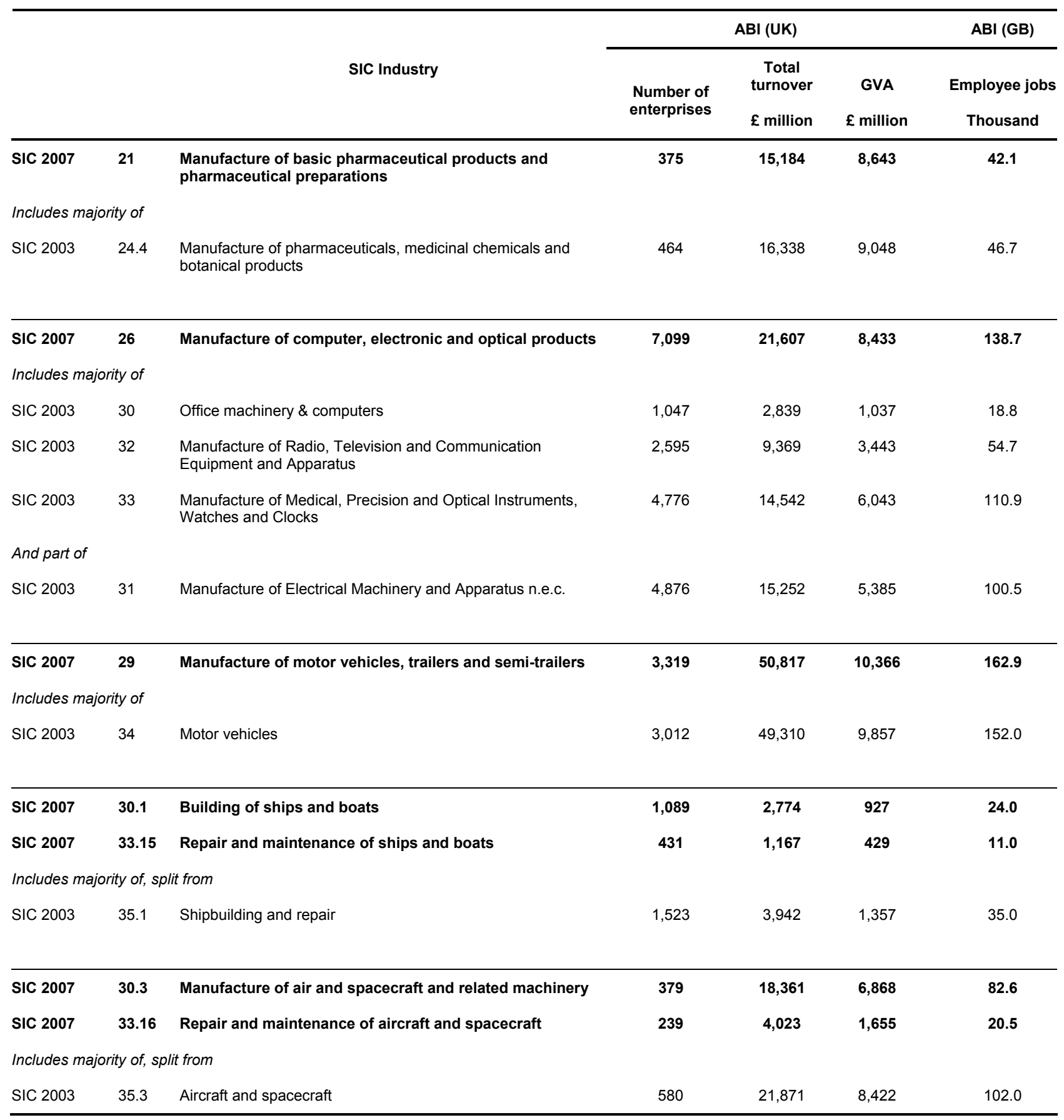

Source: Annual Business Inquiry, ONS 
Figure 3 Fragmentation of SIC 2003 code 24.4 - Manufacture of pharmaceuticals, medicinal chemicals \& botanical products, December 2009

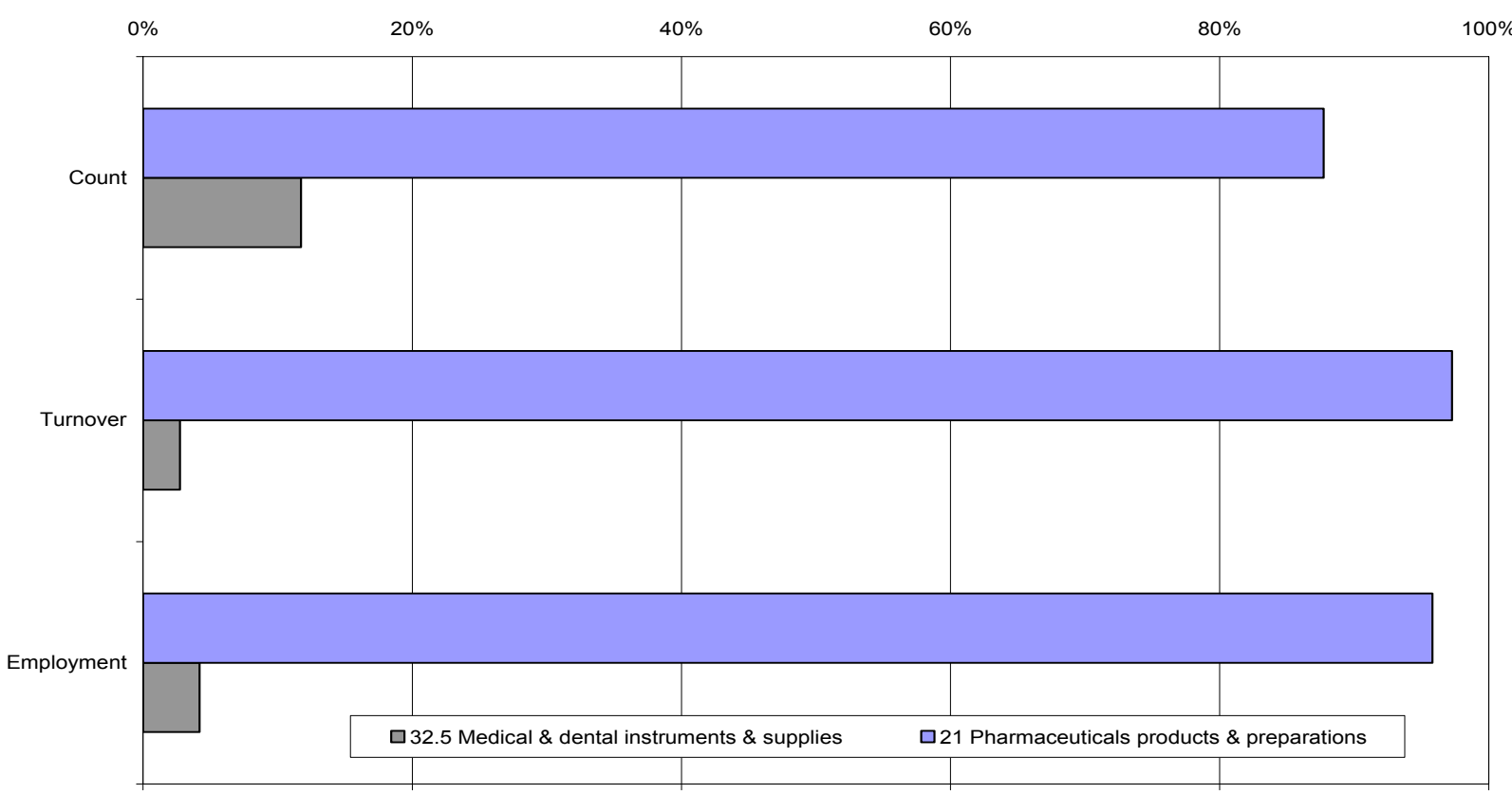

Source: IDBR conversion matrices, ONS

Figure 4 Composition of SIC 2007 code 26 - Manufacture of computer, electronic \& optical products

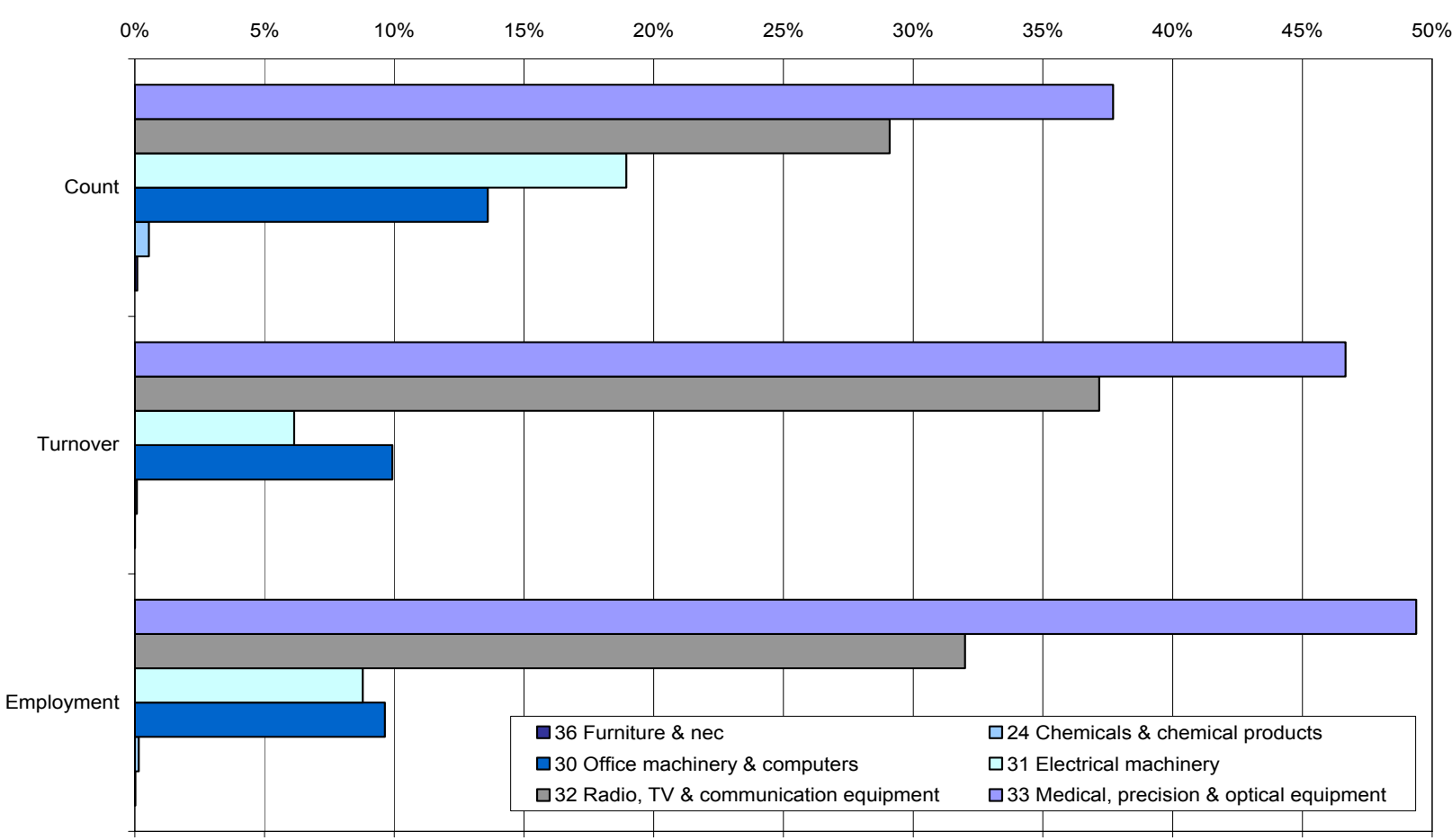

Source: IDBR conversion matrices, ONS 


\section{Professional and business services}

A major improvement in services has been the split of SIC 2003 section K - Real estate, renting and other business activities into four new sections (see Table 1). Table 6 shows the output within these new sections at a 2-digit division level. The majority of the content for sections $\mathrm{L}$ to $\mathrm{N}$ has come from the old SIC 2003 section K. However, the new section J - Information and communication includes content from Manufacturing (publishing) and Other services (Film and TV) with Computer services coming from section $\mathrm{K}$. There has been a lot of fragmentation of the old SIC 2003 content and in a number of cases 3-digit groups have now become 2-digit classes, which is a welcome improvement.

\section{Table 6 Detailed content of new Information \& communication and Business services sections, 2008}

\begin{tabular}{|c|c|c|c|c|c|}
\hline SIC2007 & Description & $\begin{array}{c}\text { No of } \\
\text { enterprises }\end{array}$ & $\begin{array}{l}\text { Turnover } \\
£ \text { billion }\end{array}$ & $\begin{array}{l}\text { GVA } \\
£ \text { billion }\end{array}$ & $\begin{array}{l}\text { Employment } \\
\text { Thousand }\end{array}$ \\
\hline $\mathbf{J}$ & Information and communication & 152,000 & 183 & 90 & 1,125 \\
\hline 58 & Publishing activities & 12,000 & 21 & 11 & 172 \\
\hline 59 & Motion picture \& TV programme production etc & 15,000 & 15 & 2 & 115 \\
\hline 60 & Programming and broadcasting activities & 2,000 & 8 & 4 & 21 \\
\hline 61 & Telecommunications & 6,000 & 64 & 29 & 215 \\
\hline 62 & Computer programming \& consultancy etc & 110,000 & 68 & 40 & 541 \\
\hline 63 & Information service activities & 8,000 & 8 & 5 & 62 \\
\hline $\mathbf{L}$ & Real estate activities & 75,000 & 45 & $\mathrm{n} / \mathrm{a}$ & 419 \\
\hline M & Professional, scientific and technical activities & 330,000 & 199 & 111 & 1,937 \\
\hline 69 & Legal and accounting services & 62,000 & 44 & 34 & 569 \\
\hline 70 & Activities of head offices; management consultancy & 117,000 & 46 & 24 & 435 \\
\hline 71 & Architectural, engineering \& technical testing etc & 69,000 & 47 & 26 & 449 \\
\hline 72 & Scientific research and development & 4,000 & 19 & 7 & 108 \\
\hline 73 & Advertising and market research & 17,000 & 26 & 11 & 152 \\
\hline 74 & Other professional, scientific \& technical activities & 59,000 & 16 & 8 & 180 \\
\hline 75 & Veterinary activities & 3,000 & 2 & 1 & 45 \\
\hline $\mathbf{N}$ & Administrative and support service activities & 156,000 & 152 & 70 & 2,240 \\
\hline 77 & Rental and leasing activities & 16,000 & 25 & 13 & 158 \\
\hline 78 & Employment activities & 20,000 & 37 & 23 & 884 \\
\hline 79 & Travel agency, tour operator \& reservation etc & 7,000 & 36 & 5 & 101 \\
\hline 80 & Security and investigation activities & 6,000 & 7 & 5 & 181 \\
\hline 81 & Services to buildings and landscapes activities & 30,000 & 15 & 8 & 558 \\
\hline 82 & Office administrative, office \& other support etc & 76,000 & 33 & 16 & 358 \\
\hline
\end{tabular}

Source: Annual Business Inquiry 
However, because of these changes and the degree of fragmentation, it is not possible to compare the activity for the same reference period for both classifications. Using 2007 SIC 2003 ABI outputs, Table 7 gives an indication of where a reasonable portion of the new content comes from.

\section{Table 7 SIC 2003 outputs which give reasonable mapping into new SIC 2007 sections J and L-N, 2007}

\begin{tabular}{|c|c|c|c|c|c|c|c|}
\hline \multirow{2}{*}{$\begin{array}{l}\text { Part or all contributes to SIC } 2007 \\
\text { division }^{1}\end{array}$} & \multicolumn{3}{|r|}{ SIC 2003} & \multirow{2}{*}{$\begin{array}{c}\text { Number of } \\
\text { enterprises } \\
\text { Thousand }\end{array}$} & \multirow{2}{*}{$\begin{array}{c}\text { Turnover } £ \\
\text { billion }\end{array}$} & \multirow{2}{*}{$\begin{array}{l}\text { GVA } £ \\
\text { billion }\end{array}$} & \multirow{2}{*}{$\begin{array}{l}\text { Employment } \\
\text { Thousand }\end{array}$} \\
\hline & Section & Detail & Description & & & & \\
\hline J Information and communication & \multicolumn{3}{|c|}{ Reasonable mapping between SIC 2003 and SIC $2007^{1}$} & & & & \\
\hline 58 Publishing activities & $\mathrm{D}$ & 22.1 & Publishing & 10 & 20 & 9 & 170 \\
\hline $\begin{array}{l}59 \text { Motion picture \& TV programme } \\
\text { production etc }\end{array}$ & $\mathrm{O}$ & 92.1 & Motion picture and video activities & 9 & 6 & 3 & 51 \\
\hline $\begin{array}{l}60 \text { Programming and broadcasting } \\
\text { activities }\end{array}$ & $\mathrm{O}$ & 92.2 & Radio and television activities & 6 & 13 & 2 & 78 \\
\hline 61 Telecommunications & 1 & 64.2 & Telecommunications & 5 & 62 & 27 & 217 \\
\hline $\begin{array}{l}62 \text { Computer programming \& consultancy } \\
\text { etc }\end{array}$ & $\mathrm{K}$ & 72 & Computer and related activities & 109 & 69 & 42 & 599 \\
\hline \multicolumn{8}{|l|}{63 Information service activities } \\
\hline L Real estate activities & $\mathrm{K}$ & 70 & Real estate activities & 110 & 55 & $\mathrm{n} / \mathrm{a}$ & 539 \\
\hline \multicolumn{8}{|l|}{$\begin{array}{l}\text { M Professional, scientific and technical } \\
\text { activities }\end{array}$} \\
\hline 69 Legal and accounting services & $\mathrm{K}$ & $74.11-12$ & Legal and accounting services & 64 & 43 & 33 & 575 \\
\hline $\begin{array}{l}70 \text { Activities of head offices; management } \\
\text { consultancy }\end{array}$ & $\mathrm{K}$ & 74.14 & Business and management consultancy & 106 & 35 & 22 & 342 \\
\hline $\begin{array}{l}71 \text { Architectural, engineering \& technical } \\
\text { testing etc }\end{array}$ & $\mathrm{K}$ & $74.2-3$ & Architectural, engineering \& technical testing & 70 & 45 & 24 & 445 \\
\hline 72 Scientific research and development & $\mathrm{K}$ & 73 & Research and Development & 3 & 13 & 6 & 102 \\
\hline 73 Advertising and market research & $\mathrm{K}$ & $74.13,74.4$ & Market research \& advertising & 17 & 24 & 8 & 153 \\
\hline 75 Veterinary activities & $\mathrm{N}$ & 85.2 & Veterinary activities & 3 & 2 & 1 & 41 \\
\hline \multicolumn{8}{|l|}{$\begin{array}{l}\mathrm{N} \text { Administrative and support service } \\
\text { activities }\end{array}$} \\
\hline 77 Rental and leasing activities & $\mathrm{K}$ & 71 & Renting of machinery and equipment & 17 & 25 & 14 & 171 \\
\hline 78 Employment activities & $\mathrm{K}$ & 74.5 & Labour recruitment and provision of personnel & 18 & 33 & 24 & 828 \\
\hline $\begin{array}{l}79 \text { Travel agency, tour operator \& } \\
\text { reservation etc }\end{array}$ & 1 & 63.3 & Activities of travel agencies etc & 7 & 36 & 5 & 107 \\
\hline 80 Security and investigation activities & $\mathrm{K}$ & 74.6 & Investigation and security activities & 6 & 6 & 5 & 179 \\
\hline $\begin{array}{l}81 \text { Services to buildings and landscapes } \\
\text { activities }\end{array}$ & $\mathrm{K}$ & 74.7 & Industrial cleaning & 14 & 8 & 5 & 455 \\
\hline $\begin{array}{l}\text { Moved or fragmented to various SIC } \\
2007 \text { divisions / sections }\end{array}$ & \multicolumn{3}{|c|}{ Rest of SIC 200374} & & & & \\
\hline Moved to K Financial services & $\mathrm{K}$ & 74.15 & Management activities of holding companies & 4 & 3 & 1 & 54 \\
\hline $\begin{array}{l}74 \text { Other professional, scientific \& } \\
\text { technical activities }\end{array}$ & $\mathrm{K}$ & 74.81 & Photographic activities & 9 & 1 & 1 & 27 \\
\hline $\begin{array}{l}82 \text { Office administrative, office \& other } \\
\text { support etc }\end{array}$ & $\mathrm{K}$ & $\begin{array}{l}74.82,85- \\
86\end{array}$ & Packaging, secretarial, translation \& call centre & 4 & 5 & 3 & 96 \\
\hline Fragmented between $74 \& 82$ & $\mathrm{~K}$ & 74.87 & Other business activities nec & 135 & 41 & 20 & 431 \\
\hline
\end{tabular}

1. Ordered according to new SIC 2007 divisions, rather than SIC 2003 classification Source: Annual Business Inquiry 


\section{Water and sewerage}

There is a significant difference in the treatment of water and sewerage activities under the old and new classifications, which, as shown in Table $\mathbf{8}$, has resulted in a large shift in activity from sewerage to water under SIC 2007. Under SIC 2003; water and sewerage were assigned to different parts of the economy with water in Production and sewerage part of Services. However, the majority of businesses involved in these activities undertook both activities and so on the Interdepartmental business register (IDBR), the companies were coded to a combined dummy division and split using data from the Water Services Regulation Authority (OFWAT). This allowed the activity to be correctly assigned to production or services.

\section{Table $8 \quad$ ABI outputs for water and sewerage}

\begin{tabular}{|c|c|c|c|c|c|c|c|c|c|c|c|}
\hline \multirow{2}{*}{$\begin{array}{l}\text { SIC } \\
2007\end{array}$} & \multirow{2}{*}{ Description } & \multicolumn{4}{|c|}{2008 Reference year } & \multirow{2}{*}{$\begin{array}{l}\text { SIC } \\
2003\end{array}$} & \multirow{2}{*}{ Description } & \multicolumn{4}{|c|}{2007 Reference year } \\
\hline & & $\begin{array}{l}\text { Number of } \\
\text { enterprises }\end{array}$ & $\begin{array}{l}\text { Total } \\
\text { turnover } \\
£ \text { million }\end{array}$ & $\begin{array}{l}\text { GVA } \\
£ \text { million }\end{array}$ & $\begin{array}{c}\text { Employment } \\
\text { Thousand }\end{array}$ & & & $\begin{array}{l}\text { Number of } \\
\text { enterprises }\end{array}$ & $\begin{array}{l}\text { Total } \\
\text { turnover } \\
£ \text { million }\end{array}$ & $\begin{array}{l}\text { GVA } \\
£ \text { million }\end{array}$ & $\begin{array}{l}\text { Employment } \\
\text { Thousand }\end{array}$ \\
\hline$E$ & $\begin{array}{l}\text { Water supply, sewerage, } \\
\text { waste management, and } \\
\text { remediation activities }\end{array}$ & 5,581 & 29,184 & 15,281 & 141 & $\begin{array}{l}\text { Total } \\
41 \& \\
90\end{array}$ & $\begin{array}{l}\text { Water supply, sewerage, } \\
\text { waste management, and } \\
\text { remediation activities }\end{array}$ & 3,551 & 19,485 & 12,372 & 111 \\
\hline 36 & $\begin{array}{l}\text { Water collection, treatment } \\
\text { and supply }\end{array}$ & 133 & 10,820 & 8,018 & 39 & 41 & $\begin{array}{l}\text { Collection, purification and } \\
\text { distribution of water }\end{array}$ & 127 & 5,546 & 4,510 & 29 \\
\hline 37 & Sewerage & 948 & 2,350 & 1,804 & 12 & 90.01 & $\begin{array}{l}\text { Collection and treatment of } \\
\text { sewage }\end{array}$ & 1,048 & 6,281 & 4,613 & 23 \\
\hline 38 & $\begin{array}{l}\text { Waste collection, treatment } \\
\text { and disposal activities; } \\
\text { materials recovery }\end{array}$ & 4,368 & 15,906 & 5,404 & 89 & 90.02 & $\begin{array}{l}\text { Collection and treatment of } \\
\text { other waste }\end{array}$ & 2,004 & 7,015 & 2,867 & 51 \\
\hline 39 & $\begin{array}{l}\text { Remediation activities and } \\
\text { other waste management } \\
\text { services }\end{array}$ & 132 & 108 & 56 & 1 & 90.03 & $\begin{array}{l}\text { Sanitation, remediation and } \\
\text { similar activities }\end{array}$ & 372 & 643 & 382 & 8 \\
\hline
\end{tabular}

Source: Annual Business Inquiry, ONS

Under SIC 2007, both activities are now part of the Production sector and are combined in the new section $\mathrm{E}$ Water supply, sewerage, waste management and remediation activities. The latter have also moved from services but as evidenced by Table 8 these have recorded a large increase in the number of businesses involved in these activities, partly due to register improvements. It is noted that in 2007 under SIC 2003 water and sewerage GVA was split approximately 50/50 whereas in 2008 under SIC 2007 the split is now approximately 80/20. Under SIC 2007 the companies are now assigned correctly using the dominance rule $^{3}$, which is why there has been a large shift from output under sewerage to water. Under SIC 2003 the treatment of water and sewerage was in some respects inconsistent with the rest of the classification, with the OFWAT split giving more of a product or activity split rather than the industry split which would have been recorded using the standard classification rules.

These differences are also related to whether outputs are recorded on a reporting unit (RU) or local unit (LU) basis. The latter is more than likely to give a split closer to an activity or product split. The estimates shown in Table 8 are based on data collected and reported on a RU basis. However from 2009 the $\mathrm{ABI} / 1$ employment data has been collected under the new Business register and 
employment survey which is reported on a LU basis. For 2008 and 2009 the new Business Register and Employment Survey (BRES) employment outputs shows 60/40 split between water and sewerage, which is similar to the employment recorded by ABI/1 under SIC 2003, using the OFWAT split. Note that from 2009 users are advised to be cautious in combining ABS financial outputs which are reported on a RU basis and BRES employment outputs which are now reported on a LU basis.

Users need to note that the classification change has had less impact on quarterly workforce employee statistics, because these are reported on a LU basis under both SIC 2003 and SIC 2007. Data are collected on a RU basis but apportioned to LUs using annual LU based ABI/1 or BRES data. The OFWAT apportionment was not used for WFJ SIC 2003. Table 9 compares the Employee Jobs data for 2007 to 2009 on a SIC 2007 and SIC 2003 basis. The data for water is the same for both classifications for each of the three years. No separate estimates were published for SIC 2003 sewerage so a direct comparison cannot be given.

\section{Table $9 \quad$ Employee Jobs for water and sewerage}

Four quarter average

\begin{tabular}{|c|c|c|c|c|c|c|c|c|c|}
\hline $\begin{array}{l}\text { SIC } \\
2007\end{array}$ & Description & 2007 & 2008 & 2009 & $\begin{array}{l}\text { SIC } \\
2003\end{array}$ & Description & 2007 & 2008 & 2009 \\
\hline$E$ & $\begin{array}{l}\text { Water supply, sewerage, } \\
\text { waste management, and } \\
\text { remediation activities }\end{array}$ & 145 & 154 & 155 & $\begin{array}{l}\text { Total } \\
41 \& \\
90\end{array}$ & $\begin{array}{l}\text { Water supply, sewerage, } \\
\text { waste management, and } \\
\text { remediation activities }\end{array}$ & 140 & 147 & 146 \\
\hline 36 & $\begin{array}{l}\text { Water collection, treatment } \\
\text { and supply }\end{array}$ & 32 & 31 & 31 & 41 & $\begin{array}{l}\text { Collection, purification and } \\
\text { distribution of water }\end{array}$ & 32 & 31 & 31 \\
\hline $37-39$ & Sewerage \& Waste etc & 113 & 124 & 124 & 90 & $\begin{array}{l}\text { Sewerage \& refuse disposal, } \\
\text { sanitation \& similar activities }\end{array}$ & 108 & 116 & 115 \\
\hline 37 & Sewerage & 17 & 17 & 16 & & & & & \\
\hline $38-39$ & $\begin{array}{l}\text { Waste collection, treatment } \\
\text { and disposal activities; } \\
\text { materials recovery; } \\
\text { Remediation activities and } \\
\text { other waste management } \\
\text { services }\end{array}$ & 97 & 106 & 108 & & & & & \\
\hline
\end{tabular}

Source: Workforce Jobs, ONS

\section{Guidance for aggregations and special sector groupings}

The European version of the new industrial classification NACE Rev2 does not include any provision or guidance for aggregation above section level, or for intermediate aggregations which are included as a sub-class in the SIC 2003 Production industries. The UN has however, given guidance for both higher level and intermediate aggregations in part 4 of their ISIC report - see UN (2008). Table 10 and Table 11 give the recommended guidance for section aggregates and subclasses; with the latter covering some service industries as well as the production industries. 
Where possible, UK users are encouraged to adopt these aggregations which will assist in providing greater coherence across SIC 2007 based outputs, both in the UK and across countries.

\section{Table 10 UN guidance for section aggregations}

\begin{tabular}{ccl}
\hline & Sections & Description \\
\hline 1 & A & Agriculture, forestry and fishing \\
2 & B-E & Manufacturing, mining and quarrying and other industrial activities \\
$2 a$ & C & of which: manufacturing \\
3 & F & Construction \\
4 & G-I & Wholesale and retail trade, transportation and storage, accommodation and food service activities \\
5 & J & Information and communication \\
6 & K & Financial and insurance activities \\
7 & L & Real estate activities \\
7 a & & of which: Imputed rent \\
8 & M-N & Professional, scientific, technical, administrative and support service activities \\
9 & O-Q & Public administration and defence, education, human health and social work activities \\
10 & R-U & Other service activities \\
\hline
\end{tabular}

Source: Table 4.1, page 274, Part 4 of UN ISIC report - see UN (2008)

Policy departments such as BIS often need to group a number of SIC industries to define sectors of special policy interest, for example Advanced manufacturing, Knowledge intensive or Information and Communication Technology (ICT) industries. The specification of these sector groupings usually involves a number of industries defined by a mix of 2-, 3-, 4- or even 5-digit SIC industries and often there is no international agreement on content, or this may need to be varied according to availability of detailed outputs. There is however, international agreement for the ICT industries with OECD having defined the content under SIC 2003 (see www.oecd.org/dataoecd/34/37/2771153.pdf ) and in collaboration with the UN this has been reviewed for SIC 2007 and published by the UN (2008).

Table 12 gives a comparison of the ICT sector using these definitions based on available ABI 2008 outputs. Since all of the required detail has not been published on both bases due to the challenge of disclosure checking across the two classifications, some of the SIC 2003 detail has been estimated by BIS. There has been considerable change in the content of the ICT sector, which is partly driven by a change in scope but also by the changes in the structure of the new classification. For example SIC 2003 industries 31.3, 33.2, 33.3, 51.43 and 71.33 have now been removed from the scope for SIC 2007 and only about half of the content of SIC 2003 industries 30, 51.84-5 and 51.86-7 are retained in the corresponding SIC 2007 industries. 


\section{Table 11 UN guidance for intermediate aggregations (sub-sections)}

\begin{tabular}{|c|c|c|c|}
\hline & $\begin{array}{l}\text { Sub- } \\
\text { section }\end{array}$ & Description & Classes \\
\hline 1 & A & Agriculture, forestry and fishing & $1-3$ \\
\hline 2 & B & Mining and quarrying & $5-9$ \\
\hline 3 & $\mathrm{CA}$ & Manufacture of food products, beverages and tobacco products & $10-12$ \\
\hline 4 & $\mathrm{CB}$ & Manufacture of textiles, wearing apparel, leather and related products & $13-15$ \\
\hline 5 & $\mathrm{CC}$ & Manufacture of wood and paper products; printing and reproduction of recorded media & $16-18$ \\
\hline 6 & $\mathrm{CD}$ & Manufacture of coke and refined petroleum products & 19 \\
\hline 7 & CE & Manufacture of chemicals and chemical products & 20 \\
\hline 8 & $\mathrm{CF}$ & Manufacture of basic pharmaceutical products and pharmaceutical preparations & 21 \\
\hline 9 & CG & Manufacture of rubber and plastics products, and other non-metallic mineral products & $22-23$ \\
\hline 10 & $\mathrm{CH}$ & Manufacture of basic metals and fabricated metal products, except machinery and equipment & $24-25$ \\
\hline 11 & $\mathrm{Cl}$ & Manufacture of computer, electronic and optical products & 26 \\
\hline 12 & CJ & Manufacture of electrical equipment & 27 \\
\hline 13 & CK & Manufacture of machinery and equipment n.e.c. & 28 \\
\hline 14 & $\mathrm{CL}$ & Manufacture of transport equipment & $29-30$ \\
\hline 15 & $\mathrm{CM}$ & Other manufacturing; repair and installation of machinery and equipment & $31-33$ \\
\hline 16 & $\mathrm{D}$ & Electricity, gas, steam and air conditioning supply & 35 \\
\hline 17 & E & Water supply; sewerage, waste management and remediation & $36-39$ \\
\hline 18 & $\mathrm{~F}$ & Construction & $41-43$ \\
\hline 19 & G & Wholesale and retail trade; repair of motor vehicles and motorcycles & $45-47$ \\
\hline 20 & $\mathrm{H}$ & Transportation and storage & $49-53$ \\
\hline 21 & 1 & Accommodation and food service activities & $55-56$ \\
\hline 22 & JA & Publishing, audiovisual and broadcasting activities & $58-60$ \\
\hline 23 & JB & Telecommunications & 61 \\
\hline 24 & $\mathrm{JC}$ & IT and other information services & $62-63$ \\
\hline 25 & K & Financial and insurance activities & $64-66$ \\
\hline 26 & L & Real estate activities & 68 \\
\hline $26 a$ & & of which: Imputed rent & \\
\hline 27 & MA & Legal, accounting, management, architecture, engineering, technical testing and analysis activities & $69-71$ \\
\hline 28 & MB & Scientific research and development & 72 \\
\hline 29 & MC & Other professional, scientific and technical activities & $73-75$ \\
\hline 30 & $\mathrm{~N}$ & Administrative and support service activities & $77-82$ \\
\hline 31 & O & Public administration and defence; compulsory social security & 84 \\
\hline 32 & $\mathrm{P}$ & Education & 85 \\
\hline 33 & QA & Human health activities & 86 \\
\hline 34 & QB & Residential care and social work activities & $87-88$ \\
\hline 35 & $\mathrm{R}$ & Arts, entertainment and recreation & $90-93$ \\
\hline 36 & S & Other service activities & $94-96$ \\
\hline 37 & T & Activities of households as employers; undifferentiated goods and services-producing activities of households for own use & $97-98$ \\
\hline 38 & $\mathrm{U}$ & Activities of extraterritorial organizations and bodies & 99 \\
\hline
\end{tabular}

Source: Table 4.2, page 275, Part 4 of UN ISIC report - see UN (2008) 


\section{Table 12 Changes in specification and content of ICT sector due to classification change, 2008}

\begin{tabular}{|c|c|c|c|c|c|c|c|}
\hline \multicolumn{2}{|c|}{ SIC 2007} & $\begin{array}{l}\text { GVA } \\
£ \text { million }\end{array}$ & $\begin{array}{l}\text { Employment } \\
\text { Thousand }\end{array}$ & \multicolumn{2}{|c|}{ SIC 2003} & $\begin{array}{l}\text { GVA } \\
£ \text { million }\end{array}$ & $\begin{array}{l}\text { Employment1 } \\
\text { Thousand }\end{array}$ \\
\hline \multicolumn{2}{|c|}{ New Total (UN ICT + Content \& media) } & 100,089 & 1,308 & & & & \\
\hline \multicolumn{2}{|c|}{ Approximate share of Whole economy ${ }^{2}$} & $7.7 \%$ & $4.1 \%$ & & & & \\
\hline \multicolumn{2}{|c|}{ New ICT (UN/OECD specification) } & 83,281 & 989 & \multicolumn{2}{|c|}{ Previous ICT (OECD specification) } & 98,634 & 1,220 \\
\hline \multicolumn{2}{|c|}{ Approximate share of Whole economy ${ }^{2}$} & $6.4 \%$ & $3.1 \%$ & \multicolumn{2}{|c|}{ Approximate share of Whole economy ${ }^{2}$} & $7.6 \%$ & $3.9 \%$ \\
\hline \multirow[t]{2}{*}{26.1} & \multirow[t]{2}{*}{ Manufacture of electronic components and boards } & 1,668 & \multirow[t]{2}{*}{31} & 32.1 & $\begin{array}{l}\text { Electronic valves and tubes and other electronic } \\
\text { components }\end{array}$ & 1,401 & 26 \\
\hline & & & & 31.3 & Insulated wire and cable ${ }^{3}$ & 480 & 9 \\
\hline 26.2 & $\begin{array}{l}\text { Manufacture of computers and peripheral } \\
\text { equipment }\end{array}$ & 597 & 12 & 30 & Office, accounting and computing machinery & 1,037 & 20 \\
\hline 26.3 & Manufacture of communication equipment & 1,422 & 27 & 32.2 & Television, radio transmitters and apparatus & 1,203 & 19 \\
\hline \multirow[t]{3}{*}{26.4} & \multirow[t]{3}{*}{ Manufacture of consumer electronics } & 723 & 11 & 32.3 & TV and radio receivers, sound or video recording etc & 838 & 14 \\
\hline & & & & 33.2 & $\begin{array}{l}\text { Instruments and appliances for measuring and } \\
\text { navigating etc }\end{array}$ & 3,085 & 57 \\
\hline & & & & 33.3 & Industrial process equipment $^{3}$ & 521 & 10 \\
\hline \multirow[t]{2}{*}{26.8} & \multirow[t]{2}{*}{ Manufacture of magnetic and optical media } & 15 & 0 & & & & \\
\hline & & & & 51.43 & Wholesale of electrical household appliances ${ }^{3}$ & 3,126 & 35 \\
\hline \multirow[t]{2}{*}{46.5} & \multirow[t]{2}{*}{$\begin{array}{l}\text { Wholesale of information and communication } \\
\text { equipment }\end{array}$} & 5,957 & 83 & \multicolumn{2}{|c|}{$\begin{array}{l}\text { 51.84-Wholesale of computer machinery etc }{ }^{3} \\
5\end{array}$} & 5,036 & 73 \\
\hline & & & & \multicolumn{2}{|r|}{$\begin{array}{l}\text { 51.86- Wholesale of electronics \& machinery used in industry } \\
7 \quad \text { etc }^{3}\end{array}$} & 8,267 & 149 \\
\hline 58.2 & Software publishing & 570 & 12 & & & & \\
\hline \multirow[t]{2}{*}{61} & \multirow[t]{2}{*}{ Telecommunications } & 28,671 & 215 & 64.2 & Telecommunications services & 28,689 & 214 \\
\hline & & & & 71.33 & $\begin{array}{l}\text { Renting of office machinery and equipment including } \\
\text { computers }^{3}\end{array}$ & 613 & 3 \\
\hline 62 & Computer programming \& consultancy etc & 39,377 & 541 & 72 & Computer and related services & 44,338 & 592 \\
\hline 63.1 & $\begin{array}{l}\text { Data processing, hosting and related activities; } \\
\text { web portals }\end{array}$ & 3,436 & 39 & & & & \\
\hline 95.1 & $\begin{array}{l}\text { Repair of computers and communication } \\
\text { equipment }\end{array}$ & 845 & 18 & & & & \\
\hline \multicolumn{2}{|c|}{ New Content and Media (UN/OECD specification) } & 16,808 & 319 & & & & \\
\hline 58.1 & $\begin{array}{l}\text { Publishing of books, periodicals and other } \\
\text { publishing activities }\end{array}$ & 9,345 & 160 & & & & \\
\hline 59 & Motion picture \& TV programme production etc & 2,092 & 115 & & & & \\
\hline 60 & Programming and broadcasting activities & 3,866 & 21 & & & & \\
\hline 63.9 & Other information service activities & 1,505 & 23 & & & & \\
\hline
\end{tabular}

1. BIS estimates from GB estimates - ratios of available UK total

2. Unbalanced ABI GVA as share of balanced National Accounts GVA / share of ABI employment to UK total Workforce Jobs

3. BIS estimates from published 2007 detail - ratios of published 2008 aggregates

Source: BIS estimates supplementing ABI data, ONS 
The other industries have a reasonable correlation but in all cases there are changes due to fragmentation of the codes on both a SIC 2003 and SIC 2007 basis. Some new content is also included under SIC 2007 notably 58.2 - software publishing, 63.1 - data processing and 95.1 repair of computers. The Content and media sector is all new, but in size is only about a fifth of the new ICT sector. The new ICT sector is now about 6.4 per cent of the UK economy, compared with 7.6 per cent on a SIC 2003 basis. This example illustrates the improvements which arise from the new classification, but also the challenges with discontinuities and the lack of available historical time-series for the new SIC 2007 based ICT and Content and media sectors.

\section{Summary of guidance to users}

There has been considerable movement of content within most industry codes and users are advised not to compare outputs on the old SIC 2003 and new SIC 2007 basis, even at a very high aggregated level. The examples given in the article serve to illustrate the changes and warn users of the difficulties of making such routine comparisons.

Workforce Jobs estimates (WFJ) are now published on a SIC 2007 basis with Employee Jobs being published down to 2-digit SIC and with backcast series available back to 1978. Some detailed outputs are also published at a GB level for industry detail below 2-digit. From 2008 reference year, Financial and employment outputs from the Annual Business Inquiry are now published on a SIC 2007 basis for all industry details from section level down to 4- and 5- digit, with some limited outputs being published on both bases for 2008. From 2009, employment statistics are being published from the new Business Register and Employment survey (BRES).

Most ONS surveys have now been converted to SIC 2007 - see Hughes (2008) and Hughes et al (2009). It is planned that all ONS outputs will have been converted to the new classification by the autumn of 2011 when National Accounts (NA) are published on the new basis. During 2011 and 2012 it is also planned to publish backcast series of some high-level aggregated NA series back to 1948 and detailed balanced outputs for the new 114 Supply and Use (SU) industries from 1992. After this date no estimates will be published on the old SIC 2003 basis and in time the old classification will no longer be maintained in the IDBR and will become unreliable so that users will need to adopt the new classification.

During this interim period, some users may now need to combine outputs which are published on a different basis, for example Workforce Jobs and NA estimates. During this interim period some outputs which are now published on a SIC 2007 basis, are still produced by ONS on the old SIC 2003 basis. For example, non-seasonally adjusted employee jobs data are still available to users on the old SIC 2003 basis on request from ONS.

SIC 2007 classification is a major revision which has given a number of significant improvements, particularly for service industries and takes account of the changes to the UK and world economy in terms of industries which have experienced high growth or contracted in recent decades. Fragmentation of the old classification has taken place at all levels of SIC detail from sections down to detailed 2-, 3-, 4- and 5-digit codes. Users need to start adopting the new classification taking into account the changes in scope, levels and shares of the economy as illustrated in this article. 


\section{Notes}

1. The European Union's industrial classification system is Nomenclature Générale des Activités Économiques dans les Communautés Européennes (NACE)

2. Until 2008, the Annual Business Inquiry $(A B I)$ was split into an employment $(A B I / 1)$ and financial inquiry $(A B I / 2)$. From 2009 these have been replaced respectively by the Business Register and Employment Survey (BRES) and the Annual Business Survey (ABS).

3. Companies may be involved in more than one industrial activity and they are assigned to the SIC code which has the largest or dominant activity using keywords and descriptions of their business

\section{Contact}

elmr@ons.gov.uk

\section{References}

Barford N (2010) 'Revisions to Workforce Jobs', Economic \& Labour Market Review, Vol 4 No 9. Available at www.statistics.gov.uk/cci/article.asp? ID =2577

Brook K and Hughes J (2009) 'Implementation of SIC 2007 across the Government Statistical Service', Economic \& Labour Market Review, Vol 3 No 8. Available at www.statistics.gov.uk/elmr/08_09/downloads/ELMR_Aug09_Brook.pdf

Hughes J (2008) 'SIC 2007: Implementation in ONS', Economic \& Labour Market Review, Vol 2 No 8. Available at www.statistics.gov.uk/elmr/08_08/downloads/ELMR_Aug08_Hughes.pdf

Hughes J, James G, Evans A and Prestwood D (2009) 'Implementation of Standard Industrial Classification 2007: December 2009 update', Vol 3 No 12. Available at www.statistics.gov.uk/elmr/12_09/downloads/ELMR_Dec09_Hughes.pdf

United Nations (2008) 'International Standard Industrial Classification of All Economic Activities (ISIC), Rev. 4. UN Economic and Social Affairs, Statistical Papers, Series M, No. 4, (see part 4). Available at http://unstats.un.org/unsd/publication/seriesM/seriesm_4rev4e.pdf 